\title{
Дионисийский комплекс идей раннего Вячеслава Иванова
}

\author{
АНДРЕА АЛЕКСАНДРОВА \\ AleXANDrov Andrea, Budapest, Mézeskalács tér 4, H-1155 \\ E-mail: alexandrovandrea@dpg.hu
}

\begin{abstract}
In this article, which is a fragment of the $\mathrm{PhD}$ dissertation just completed, I have analyzed the motif of Dionysos in Vyacheslav Ivanov's book Po Zvezdam. In the first years after Ivanov's return into Russia from abroad, that is approximately from 1905 to 1909 , this motif was one of the innermost parts of his message to the Russian readership.

Although in the essay Nietzsche $i$ Dionis Ivanov declares that he accepts the Nietzsche's interpretation of Dionysos, step by step he fills the motif with a different content, reinterpreting it in the light of his own ideas. "Dionysos of Ivanov" comprises a group of various ideas, which I expounded systematically in the beginning of the present article. These religious and philosophical ideas are parts of a coherent system, having its own ontology, anthropology and epistemology. As the earlier draft $O$ mnogobožii testifies, the same ideas, without any significant changes, existed in the thought of Ivanov from, at least, 1901 or 1902. Their development could be traced in the author's writings of different genres: in his study Ellinskaja religija stradajuščego boga, poetry, and essays.

A specific feature of the book Po Zvezdam is that the Dionysian complex of ideas is expressed in two parallel lines of motifs - in mythological and Christian line. Both lines are equally intended to represent Ivanov's religious-philosophical ideas, although sometimes these ideas appear in the book developed directly in philosophical terms. One can say that Ivanov expresses his Dionysian world-view parallelly in three languages, or three different sets of terms: mythological, Christian, and philosophical. I established also the priority of the underlying system of religious-philosophical ideas over the motif structure of the book Po Zvezdam.
\end{abstract}

Keywords: Vyacheslav Ivanov, the motif of Dionysos, Po Zvezdam

Данная работа имеет своей целью анализ дионисийских идей в сборнике эссе «По звездам» Вячеслава Иванова. Угол зрения, предложенный мною, особый в том смысле, что в центре моих исследований стоит именно Дионис ивановский, или, говоря иначе, комплекс идей, связанный с именем Диониса Ивановым. Конечно, в восприятии Диониса Ивановым присутствует определенная традиция, но меня, в первую очередь, занимает не тот вопрос, как модифицируется Ивановым Дионис-античный, Дионис-орфический или Дионис-ницшеанский. Главный вопрос данной работы - каков этот мотив в книге «По звездам», как разнородные элементы связаны в нем в единство.

В работе не ставится вопрос, какое отношение имеет концепция Диониса к убеждениям самого Иванова: предмет моих исследований отчетливо выстраивающийся мотивный ряд в его творчестве, а не вероисповедание автора мотива. Мне кажется, что в годы, когда писались статьи данного сборника, к Иванову вполне могут быть применены его собственные слова, сказанные о Шиллере: 
[Шиллер] всегда обращается к толпе, (...) его поза перспективна, а голос условно изменен и усилен. Но он не только лицедей и вития: он жрец и мистагог... [IV, 172] $]^{1}$

Таким образом, и Диониса Вяч. Иванова скорее стоит рассматривать как ядро его сообщения «толпе» на первом этапе российского периода его творчества, т.е. в годы 1904-1909.

В том, что Дионис является главным героем произведений раннего Иванова, нет сомнений. О нем были прочитаны знаменитые парижские лекции 1903 г. [I, 59], принесшие лектору возможность творческих контактов с художественной Россией рубежа веков. На основе этих лекций Ивановым была написана серия статей «Эллинская религия страдающего бога» и «Религия Диониса». Эти статьи, печатавшиеся с января 1904 г. в журнале «Новый путь» а затем в «Вопросах жизни», явились первым мощно прогремевшим в петербургской символистской среде ивановским словом, несмотря на то, что выход в свет первого тома лирики Иванова - «Кормчие звезды», в 1903 г. - предшествовал им. Эта серия статей выдержана в жанре научного исследования и претендует на восприятие в качестве работы историка и филолога-классика. Параллельно с ними Иванов выступает и в другом прозаическом жанpe: с марта 1904 г. он начинает публиковать свои статьи-эссе в журналах «Весы», из которых впоследствии он составит отдельный том вышедший в свет в 1909 г. сборник «По звездам».

При чтении этой книги сразу бросается в глаза, что Дионису и в ней отведено центральное место. Уже одно то, что из 19 статей, помещенных в сборнике, в 14 звучит имя Диониса, говорит о многом. Линеарная структура книги, в свою очередь, тоже выстраивается «от Диониса и до Диониса»: в начале первого эссе, «Ницше и Дионис», фигурирует миф о полководце Эврипиле, обезумевшем, взглянув на идола Диониса [I, 715]; завершает же книгу эссе «Ты Еси», в последнем абзаце которого тоже упоминается Дионис, растерзанный титанами [III, 268].

В первой части работы мне хотелось бы проследить, во-первых, каковы идеи, вплетенные в мотив Диониса; во-вторых, какова их судьба в рассматриваемом сборнике, какие трансформации они претерпевают. Во второй же части статьи я ставлю вопрос о месте мотива в творчестве Иванова, о его корнях в ранних набросках автора, о поэтических параллелях, о месте его в сборнике «По звездам» и также о его будущем вне рамок данного сборника.

\section{1. «Трагическая вина Ницше...» [I, 725]}

Первое эссе книги, «Ницше и Дионис», особенно значительно для нашей темы не только тем, что в нем содержится первая и самая под-

1 Произведения Вячеслава Иванова я цитирую по изданию Иванов В. И. Собрание сочинений, I-IV. Брюссель 1971-1987. Ссылки на них я даю в тексте и указываю римскими цифрами том, арабскими - страницу.

Studia Slavica Hung. 46 (2001) 
робная во всей эссеистике Иванова характеристика концепта Диониса. Важнее, что само эссе представляет собой своеобразный культурный жест: в нем Иванов постепенно «отбирает» Диониса у Ницше. Как именно?

В качестве рамки основной части текста служит миф о полководцеЭврипиле. Судьба Эврипила представлена как прообраз судьбы Ф. Ницше, а связывает их Дионис, открыв которого оба «героя» [I, 716] обезумели [I, 715 и 726]. Безумие, о котором говорится в самых акцентированных частях текста, в начале и конце, становится важнейшим аттрибутом «ивановского Ницше». В понимании же Иванова2 безумие - явление двойственное. Это - особое состояние, наступающее вследствие мистического опыта. Его оценка («правое» или «неправое» безумие) зависит от особенностей позиции, которую при этом занимает человек, претерпевающий его. Оно превращается в душевную болезнь в том случае, если испытывающий безумие пребывает в «богопротивлении», т.е. утверждает себя в обособлении, а то и в противостоянии посетившему его божеству.

В фигуре безумца-Ницше Иванов также подчеркивает присущую его герою противоречивость. «Двойственность его даров» образно представлена как противоположность духовного зрения и духовного слуха [I, 717], которая являет в нем конфликт аполлонийского и дионисова начал [I, 718]. Стоит отметить, что мотив «духовного слуха духовного зрения» один из повторяющихся в сборнике «По звездам» ${ }^{3}$. В ивановской системе оба аттрибута одновременно присущи поэтутеургу, гармонизирующему в себе аполлонийское (видение) и дионисийское (звуки) начала. Прототипом же поэта-теурга является Орфей, в котором, по Иванову, два противоборствующих начала уравновешены ${ }^{4}$. Можно заключить, что герой ивановского эссе, Ницше, представлен автором как антипод Орфея, в котором «уши» и «глаза» находятся в роковом разладе: пророчески открыв заново Диониса, сам он до своего открытия не дорос, недопонял всей глубины дионисийства и не вынес его религиозно-жизненных последствий.

Стратегия Иванова по отношению к ницшеанскому наследию следующая: постулируя изначальный разлад в самом Ницше, оказывается оправданным сохранить некоторые его идеи, с одной стороны, и внести в них корректуры во имя «подлинного Диониса», с другой. Основная

2 Кроме статьи «Ницше и Дионис» (1094) [I, 716, 718, 719, 720, 726] этот мотив фигурирует в сборнике «По звездам» в эссе «Символика эстетических начал» (1905) [I, 828, 830], «Идея неприятия мира» (1906) [III, 79, 84, 88], «Спорады»-V (1909) [III, 123] и «Ты еси» (1907) [III, 266].

${ }^{3}$ Кроме статьи «Ницше и Дионис» см. в эссе «Поэт и чернь» (1904) [I, 711], «Копье Афины» (1904) [I, 727-728 и 731], «Две стихии в современном символизме» (1908) [II, 539].

${ }^{4}$ Силард Л. «Орфей растерзанный» и наследие орфизма: Studia Slavica Hung. 41 (1996) 215. 
часть текста, обрамленная историей Эврипила, строится как ряд противопоставлений. Поначалу противопоставляются глаза Ницше его ушам; затем Ницше - Дионису, открытому, но недопонятому им; потом культурное поведение Ницше - важнейшим собственным («правильным») идеям; и, наконец, его Сверхчеловек - Дионису, кем был изначально вдохновлен. С нашей точки зрения второстепенно, насколько «верно» изображение личности Ницше и интерпретация его идей Ивановым. Также не станем предпринимать исследования, насколько научно оправдан образ Диониса, нарисованный Ивановым. Главное для нас, что во всем ряде противоставлений присутствуют две стороны: исправляемый и исправляющий. Им же соответствуют оппозиционные пары «эстетическое - религиозное» [I, 720], «неверие - веpa» [I, 722], «фикция - видение» [I, 723], и, в конечном итоге, Ницше Иванов. Изложение же собственно ивановского представления о дионисийстве начинается со слов «Дионис есть ...» [I, 718].

\section{2. «Дионис есть...»}

Идеи, связанные с именем Диониса в эссеистике Вячеслава Иванова, образуют два взаимосвязанных круга. Первый аспект может быть назван онтологическим: сюда относятся высказывания о природе Бога, мира и человека, а также об отношении между ними. Второй аспект гносеологический и касается возможностей познания Бога и мира человеком, тех путей и условий, которые могут привести к его осуществлению.

Но прежде чем приступить к их рассмотрению, нужно сделать оговорку методического характера. Материал моих исследований целая книга, которая содержит 19 эссе разной длины. Этот большой корпус текстов объемлет по времени 6 лет: первые статьи датированы 1904-м г., а последние - 1909. Период этот чрезвычайно значителен для Вяч. Иванова, как в творческом плане, так и в плане личном. Настолько, что середина этого периода нередко выделяется исследователями ${ }^{5}$ как водораздел в развитии его мировоззрения. Существует мнение, что смерть Л. Д. Зиновьевой-Аннибал, последовавший за нею период кризиса, а затем мистические опыты Иванова, в некоторой мере под руководством А. Р. Минцловой, привели к видимому изменению в его мироощущении, в его религиозных и эстетических воззрениях. Я, со своей стороны, придерживаюсь другого мнения и считаю, что обнаруживающееся в ивановской эссеистике мировосприятие весьма цельно и постоянно, и идеи о Боге, о мире и человеке не меняются по существу

${ }^{5}$ CM.: CARPI G. Mitopoiesi e ideologia: Vjačeslav I. Ivanov teorico del simbolismo. Lucca 1994, 53-70.; также: Обатнин Г. Вячеслав Иванов и смерть Л. Д. Зиновьевой-Аннибал: концепция «реализма»: Studia Russica Helsingiensia et Tartuensia V. Модернизм и постмодернизм в русской литературе и культуре. Helsinki 1996, 145-158.

Studia Slavica Hung. 46 (2001) 
от 1904 г. до самого 1909. Однако разные аспекты одного и того же комплекса проблем могут быть выражены, говоря терминами Иванова, разными мифологемами и философемами, и с годами одна из них сменяется другой. Но это указывает, повторяю, на изменение лишь угла зрения. Мой метод заключается в том, чтобы свести воедино разбросанные по разным эссе идеи и показать, что система их действительно едина, и что одни и те же «атомарные идеи» можно найти на протяжении всего периода, хотя порою и в разных формулировках. С тем, чтобы проследить, как в разные годы данного периода доминируют разные аспекты и формулировки той же самой идеи, я буду указывать в скобках дату написания рассматриваемых текстов.

\section{А. «... божественное всеединство Сущего...»}

Дионис есть божественное всеединство Сущего в его жертвенном разлучении и страдальном пресуществлении во вселикое, призрачно колеблющееся между возникновением и исчезновением, Ничто (...) мира. Бога страдающего извечная жертва и восстание вечное - такова религиозная идея Дионисова оргиазма [1904: I, 718].

В интерпретации Иванова обряд Диониса имеет религиозную идею - определенный взгляд на Бога и мир - и эта идея выражена в самой фигуре Диониса. Согласно этой идее Бог и мир, с одной стороны, кардинально различаются. Богу присуще бытие - мир колеблется между возникновением и исчезновением, то есть не чистый призрак, но и не нечто однозначно сущее. Богу присуще единство, его имя - Сущий: он есть то Единое, что существует. Мир же имеет аттрибут множественности, «вселикости». Но, с другой стороны, Бог и мир друг от друга не отделены, между ними нет непроходимой пропасти, наоборот: Бог «пресуществляется» в мир. Этот акт для Бога означает страдание: вот о чем говорят для Иванова мифологемы «страдающего Бога» и «вечной жертвы»6. Переходя из Единства во множественность, божественный луч в себе разлучается, преломляется. [1904: II, 78]. Участвуя в мире, Бог частично умирает, «ибо воплощение - смерть для Бога» [1908: III, 129]. Потеря Богом своей целостности и безусловности своего бытия ради пресуществления в мир выражается в рамках ивановской системы в образе растерзанного титанами Диониса7

Есть «упоения на краю мрачной бездны» (...) Дионис, бог нисхождения как разрыва, Дионис - жертва божественная, - отрок, заглянувший в темное зеркало и растерзанный внезапно обставшими младенца титанами [1905: I, 828].

${ }^{6}$ Кроме статьи «Ницше и Дионис» см. в эссе «Новые маски» (1904) [II, 77-78]; «Предчувствия и предвестия» (1906) [II, 94]; «Идея неприятия мира» (1906) [III, 81]; «Ты еси» (1907) [III, 268]; «Эстетика и исповедание» (1908) [II, 570] и «Древний ужас» (1909) [III, 105].

${ }^{7}$ Кроме статьи «Символика эстетических начал» см. еще в эссе «Ницше и Дионис» (1904) [I, 718] и «Ты еси» (1907) [III, 267]. 
С иной стороны, этот акт именно потому жертва, что пресуществление Бога в мир как бы преобразует, поднимает последний божественное страдание приводит к бытию призрачное «Ничто» мира. В этом аспекте Иванов усматривает «тайну Сына» и в нем видит главную схожесть Диониса с Христом [ср. 1904: I, 718].

Божественное ниспосылает свет свой в темное вещество, чтобы и оно было проникнуто светом. Из плана в план божественного всеединства, из одной иерархии творения в другую нисходит Логос, и свет во тьме светится, и тьма его не объемлет. Здесь тайна второй ипостаси, тайна Сына [1909: III, 333].

В результате этого жертвенного акта «Единое становится многоликим» [1909: III, 117], «единство — множественным» [1908: III, 130]. A с точки зрения мира наоборот: «sub specie metamorphoseos ... феномен был познан как маска бога» [1909: III, 117]. Согласно часто повторяющейся мысли Иванова, «истинно дионисийское миропонимание требует, чтобы наша личина была в сознании нашем ликом самого многоликого бога» [1904: I, 726]

В ивановской системе отсюда уже прямо следует идея о «сверхчувственной связи сущего» [1908: II, 558], ведь каждое явление таит в себе Сущего, и в Нем всё - едино 9 . Нечто схожее выражено в идее «круговой поруки живых сил» [1905: I, 824], которой Иванов, по собственным словам, обязан Достоевскому [1904: II, 76], но которую он узнает и в мысли индусов [1906: III, 81].

Роптать ли нам, если всю кровь и весь сок наших переживаний сила вещей делает достоянием вселенским, и даже одинокий и нераздельный порыв наш учитывается круговою порукой жизни? [1905: I, 838].

По мысли Иванова, как раз это есть общее мира с Богом, это превращает бессмысленное страдание мира и человека в жертву:

В мире - круговая порука живых сил, равно вины и благодати; жертва расплата одного, собою одним, за вселенскую поруку [1905: I, 824].

Эта же мысль появляется в ивановских эссе в формулировке «всеединство страдания», «сораспятие в духе со всем» и «сораспятие вселенское» [1904: 76 и 78].

Последний аспект взаимоотношения бога и мира есть восприятие миром нисходящего к нему божественного луча. У Иванова этот аспект заключен в образе радуги ${ }^{10}$, которая отображает многоплановость, многоярусность мирозданья, «иерархию планов божественного все-

\footnotetext{
8 Кроме статьи «Ницше и Дионис» см. в эссе «Новые маски» (1904) [II, 77]; «Предчувствия и предвестия» (1906) [II, 94]; «Спорады»-II (1908) [III, 116].

9 Кроме эссе «Две стихии в современном символизме» см. статьи «Байрон и идея анархии» (1908) [IV, 291]; «О „Цыганах“ Пушкина» (1908) [IV, 318]; «Спорады» - VI (1908) [III, 129-131].

10 Кроме эссе «Две стихии в современном символизме» см. статьи «Ницше и Дионис» (1904) [I, 719-720]; «О русской идее» (1909) [III, 333]. Вне рамок данного сборника радуга наглядно представлена на рисунке № 2 к статье «О границах искусства» [II, 645]. 
единства» [1908: II, 537]. Многоплановое мирозданье динамично: планы находятся в общении, на что указывает, по Иванову, термин «соответствия». Низшая реальность при этом, как кристалл, отражает высшую [1908: II, 557]. В образе кристалла соединены свойства «несовершенного зеркала» и вещественной, твердой материи: он частично пропускает луч Логоса, частично же поглощает и преломляет его.

Действительность - несовершенное зеркало иной действительности, события которой сделались бы событиями в нашей сфере, если бы часть их не отвращалась силами, чью совокупность и чье взаимодействие мы называем Необходимостью. В этом смысле можно сказать, что действительность - кристаллизация возможного [1908: III, 113].

Эта же идея выражена в статье «Древний ужас», где Необходимость представлена Ивановым как «плоть мира», то есть «Душа мира в аспекте матери»:

Необходимость природная есть причинная связь явлений; но каждое явление и каждый миг мимолетний не чадо безмужней матери, а чадо брака между женскою причиною и мужеским семенем Логоса. И свет этого семени во тьме светит, и тьма его не объемлет [1909: III, 109].

Эти слова хорошо демонстрируют многоаспектность самого ивановского текста: в нем соединены отсылки в область историософии; в область философии мужского и женского, пола и любви; а также в область эстетики. Эстетический аспект проблемы был затронут Ивановым еще в 1905 г., когда он, связывая красоту с нисхождением, произнес:

так Красота, всякий раз снова нисходя на землю с дарами неба, знаменует вечное обручение Духа с Душой Мира... [1905: I, 827].

Поэтому эстетическое в ивановской системе немыслимо без религиозного измерения, и поэтому он может назвать творчество художника (хотя и не без оговорок) теургией.

...художники ... суть служители высших откровений, ибо высочайшее не может низойти в сферу земного сознания иначе, если не облечется в земную сгущенность призрачного вещества [1908: III, 117].

$$
\text { Б. «... но что, если мы сами - живое зеркало ...?» [III, 125] }
$$

Второй слой дионисийских идей Вяч. Иванова можно назвать антропологическим. В эссе 1904 г. «Ницше и Дионис» подчеркнуто, что в дионисийстве отражено нечто существенное в природе человека и эта идея остается одной из важнейших до 1909 г. («Спорады», «Древний ужас»). Данная особенность человеческой природы открывается в мистике Дионисова культа, которая

...в каждый миг истинного экстаза отображает всю тайну вечности в живом зеркале внутреннего, сверхличного события исступленной души. Здесь Дионис - вечное чудо мирового сердца в сердце человеческом...» [1904: I, 719]. 
Это явление Иванов обозначает терминами «боговмещения» [1904: I, 719] и «обожествления человека», предусматривая два пути его:

...чрез благодатное ... приближение Божества к человеческой душе, доходящее до полного их слияния, или чрез внутреннее прозрение на истинную и непреходящую сущность я, на «Самого» в я («Атман» браманской философии) [1904: I, 723].

Для нашей темы особенный интерес представляет второй путь обожествления, когда перед человеком открывается дотоле неощутимое измерение собственного существа. У Иванова это выражено в образе «воплощения в нас воскресшего Диониса» [1904: I, 716]11 То же самое высшее измерение может открыться человеку, когда он глядит на другого человека, как и в драматическом действе:

Мы хотим проникнуть за маску и за действие, в умопостигаемый характер лица, и прозреть его внутреннюю маску; но это уже личина Вечности, - не наш ли собственный внутренний двойник эта духовная, безликая личина? [1904: II, 78].

В образной паре лика и личины Ивановым выражено соотношение эмпирического я и его непреходящей сущности. Оно состоит в единстве скрытости и явленности: эмпирическая личность не только заслоняет собою умопостигаемый характер, но и являет его. «Личина» своего $я$ осознается человеком как «лик самого многоликого бога» [1904: I, 726]. Маска - это символ, «тело тайны и ..., „правда,, ее неуловима, как тень Элизия, если разрушат ее живой покров» [1908: III, 116]. В отношении к человеку это значит, что он тоже скрывает-являет живущего в нем «Самого», хотя чаще всего не знает об этом и «мгновенным напоминанием» служит ему как раз «потусторонний взор вещей маски» [1904: II, 78]. В пятой части «Спорад», которая носит заглавие «О Дионисе и культуре», Иванов пишет:

...но что, если мы, глядящиеся в зеркало и видящие ответный взгляд, сами живое зеркало, и наше зрящее око - только отсвет и отражение живого ока, вперенного в нас? Бросая от себя луч вовне, не приняли ли мы его раньше извне, отразив в своем микрокосме вселенскую тайну? И не в том ли эта тайна, что ... в зеркальной Вечности Надир

Глядит в Зенит зеницею Зенита...

(«Кормчие Звезды»)» [1909: III, 125].

Годом раньше, в очерке, составившем шестую часть «Спорад», Иванов высказывается сходным образом:

Во имя этой связи он [человек], созерцая безграничный мир, говорит ему: «ты я», с тем же правом, с каким Дух макрокосма, озирая себя бесчисленными своими очами, говорит человеческой монаде: «ты - я». Зенит глядит в Надир, Надир в Зенит: два ока, наведенные одно на другое, два живых зеркала, отражающие каждое душу другого. ... Звездами говорит «Сам» в человеке своему я... [1908: III, 131].

Из этих двух цитат явствует, что у Иванова образ «живого зеркала» связывает две области антропологических представлений. Человек от-

11 Этот же образ встречается в эссе «Новые маски» [1904: II, 79]. 
ражает собою «вперенного в него „Самого“», с одной стороны, и безграничный мир, с другой. Более того: человек именно той своей чертой «отображает вселенскую тайну», что соединяет в себе две природы, эмпирическую (я) и божественную (Сам), как в мире присутствуют «Сущий» и «Ничто». В этом смысле тожественны микрокосм и макрокосм.

Этим мы уже почти полностью очертили те представления о человеческой природе, которые вырисовываются из сборника «По звездам». Если мы все же не останавливаемся здесь, а продолжаем прослеживать антропологические взгляды по другим эссе, то делаем это с двумя целями. Во-первых, чтобы показать, что эти идеи присутствуют на протяжении всего рассматриваемого периода, и что в них нет существенных изменений с 1904 до 1909 г.; и, во-вторых, чтобы установить, с какими мотивами и символами соединены те же идеи, помимо мифологемы Диониса.

Если ивановская система строится на тожестве макрокосма и микрокосма, то человек, так же как и вселенная, соединяет в себе две, в основе своей различающиеся природы. Говоря о мире, Иванов назвал их «Сущим» и «мэоном» [1904: I, 718]; в этом же году, в статье «Копье Афины» он различает те же самые начала в человеческом естестве ${ }^{22}$ :

Не нужно быть чрезмерно пристрастным к метафизическому образу мышления, чтобы обличить жизнь как становление и, следовательно, небытие; чтобы осмыслить свое эмпирическое существование как мэон (не-сущее); чтобы осознать, что синтетическое условие становления есть бытие и что существует для ищущего, подобно математическому пределу бесконечно приближающихся величин, некоторое $\boldsymbol{Я}$ во мне; как постулат моего не-я, или я - мэона [1904: I, 733].

Ясно, что этот отрывок не вносит новых идей в антропологию, как она выражена в эссе «Ницше и Дионис», и все-таки статья «Копье Афины» имеет для нашей темы большой интерес, поскольку в ней были введены в описанный круг антропологических идей такие известнейшие ивановские философемы как «Ты Еси» или «Fio ergo non sum»:

Кто волит своего я, тот знает, что не обрел его. Fio ergo non sum. Я становлюсь: итак, не есмь. Жизнь во времени - умирание. Жизнь - цепь моих двойников, отрицающих, умерщвляющих один другого. Где - я? Вот вопрос, который ставит древнее и вещее «Познай самого себя», начертанное на дельфийском храме подле другого таинственного изречения: «Ты еси» (عí) [1904: I, 732-733].

В зеркале этих формулировок эссе 1907 г. «Ты еси» предстает уже не как нечто принципиально новое в ивановской картине природы человека, но наоборот: его новизна будет лишь новизной изложения. Там те же мысли излагаются на другом языке: на языке психологии. С другой стороны, очевидно, подобный перевод, из мифологии и

12 Кроме статей «Ницше и Дионис» и «Копье Афины» этот мотив фигурирует в сборнике «По звездам» в эссе «Кризис индивидуализма» (1905) [I, 837]; «Идея неприятия мира» (1906) [III, 90]; «Ты еси» (1907) [III, 263]; «О „Цыганах“ Пушкина» (1908) [IV, 320]; «О русской идее» (1909) [III, 330-331]. 
философии в психологию и наоборот, имеет свою предпосылку в тезисе о тожественности микрокосма и макрокосма.

Кроме «я-мэона» и «Я-Сущего» в ивановской антропологии присутствует еще понятие «Я-вселенского», которое указывает как раз на эту тожественность. Ведь человек именно в том тожественен вселенной, что в его природе есть выше его самого, что существует более его эмпирического я. Я-Сущий, божественное начало есть то, что реально осуществляет всеединство всего сущего. Триединая природа человека очень четко сформулирована в шестой части «Спорад», «О законе и связи»:

Есть в человеке $\boldsymbol{Я}$ высшее, его святое святых, цель его постижения и предел приближения, божественное средоточие микрокосма. И есть я, определенное границами эмпирической личности. Для первого $Я$ второе - смерть, ибо воплощение - смерть для Бога; для второго приближение к первому - тоска Психеи по огненной смерти. И есть, наконец, Все-Я, объемлющее вселенную [1908: III, 129].

В ивановской мысли очень большой акцент стоит на том обстоятельстве, что человек, как правило, не осознает ни божественное измерение своего существа, ни, как следствие, свое единство с универсумом. Отожествление себя со своим эмпирическим я предстает в ивановских текстах как забвение, точнее - как самозабвение живущего в человеке Сущего. Мифологема «себя забывшего и забытого бога» поэтому занимает столь важное место в текстах раннего Иванова. Она нередко встречается в эссе сборника «По звездам» ${ }^{13}$; мы приведем лишь два из таких мест.

Из избытка своей безграничности Божественное пожелало невозможного. И невозможное совершилось: Божественное забыло себя и опозналось разделенным в мире граней [1905: I, 825].

$$
\begin{aligned}
& \text { Я, забывший, я, забвенный, } \\
& \text { Встану некогда из гроба, } \\
& \text { Встречу свет Твой в белом льне. } \\
& \text { Лик явленный, сокровенный } \\
& \text { Мы сольем, воскреснув, оба: } \\
& \text { Я - в тебе, и Ты - во мне. } \\
& \text { («Cor Ardens») [1907: III, 134]. }
\end{aligned}
$$

Стихи эти приобретают особое значение в эссе, поскольку они выделены в нем в двух смыслах: в качестве автоцитаты и, с другой стороны, как стихотворение в прозаическом тексте. Для нас же в них примечательно, кроме мифологемы себя забывшего и забытого бога, присутствие еще одного ивановского символа. Евангельская история о воскрешении Лазаря выступает как эквивалент моменту припоминания: когда человек осознает свои, дотоле неизвестные себе самому измерения собственной природы, это, по мысли Иванова, равно восстано-

13 Кроме статьи «Символика эстетических начал» (1905) [I, 823 и 825] см. еще в эссе «Копье Афины» (1904) [I, 837]; «Новые маски» (1904) [II, 78]; «Спорады»-VII (1907) [III, 134]; «Ты еси» (1907) [III, 263 и 265]. 
влению прежнего могущества, воскрешению. Припоминанию может дать толчок как внешнее, так и внутреннее событие, но, в любом случае, в основе этого процесса лежит мистический опыт, будь то опыт своего тожества со вселенной или встреча с божественным в глубине человеческой души, как это описано в эссе «Ты еси». Конечно, обретенное новое знание в корне изменяет отношение человека к бытию: это и есть тот поворот всего существа, что составляет один из аспектов ивановской «метанойи».

Последний момент ивановской антропологии есть телесность. Скажу об этой проблеме кратко, ведь в данном сборнике она не занимает значительного места. Тем не менее стоит упоминуть о ней, поскольку она свидетельствует о полной параллельности строения человека и вселенной в ивановской системе. В тексте «Древний ужас» мы читаем, что «внешнее человека, его плоть - земля его. Это жена, Душа Мира в нем» [1909: III, 108].

Человек, по Иванову, состоит из «Неба» и «Земли» ${ }^{4}$, то есть из «ЯСущего» и «я-эмпирического», частью которого является плоть. Подобно этому и мир имеет в себе «Сущее» и «мэон», т.е. явления, которые суть чада Логоса и Необходимости. Совпадают же они, мир и человек, взятые в своей целостности. В отношении к миру это именуется «Всеединством», в случае человека - «Все-я». Такую картину мира знаменует Иванов термином «Панантропизма», и в этом смысле он говорит, что «имя земле и миру — Всечеловек» [1909: III, 118].

Тою же мыслью заканчивается и эссе «Ты еси», и, таким образом, на этой ноте завершается весь сборник «По звездам»:

Ибо то, что религиозная мысль называет первобытным раем, есть нормальное отношение макрокосма и микрокосма, - ноуменальное всечувствование вещей как равно и тожественно сущих вместе внутри и вне человека, сына Божия; ... [1907: III, 268].

\section{В. «... исступление из граней эмпирического я...» [1904: I, 719]}

Тот факт, что макрокосм и микрокосм тожественны, еще не означает, по мысли Иванова, что человек об этом знает. Наоборот, в ивановской системе чувствовать это есть благо, не всем и не всегда доступное, «первобытный рай», в который современный человек может проникнуть только в редкие минуты экстаза. Но почему именно экстаза что означает этот «выход из себя», какова его оценка в текстах Иванова ${ }^{15}$ ?

В его процессе Иванов различает два этапа, которые проходит

14 Эту формулировку можно найти в эссе «Ты еси» (1907) [III, 265]; «О русской идее» (1908) [III, 330-331]; «Древний ужас» (1909) [III, 108].

15 Об этом см. в эссе «Ницше и Дионис» (1904) [I, 719]; «Символика эстетических начал» (1905) [I, 830]; «Новые маски» (1904) [II, 77]; «О Шиллере» (1905) [IV, 178]; «Байрон и идея анархии» (1908) [IV, 291]; «Две стихии в современном символизме» (1908) [II, 553]; «Ты еси» (1907) [III, 266]. 
человек. Первый из них - «исступление из граней эмпирического я», «потеря себя в хаосе». Затем следует «приобщение к единству я вселенского», «новое обретение себя в боге» [1904: I, 719]. Но это «я-вселенское» есть нечто новое, уже не прежнее «я-эмпирическое». В экстазе происходит «оргийное самозабвение» [1904: I, 719], «полное слияние Божества с человеческой душой»16 [1904: I, 723]: «Бог разбивает грани раздельного небытия» ${ }^{17}$ [1904: I, 719]. Если вспомнить, что в мифологеме себя забывшего и забытого бога «Божественное забыло себя и опозналось разделенным в мире граней» [1905: I, 825], то видно, что в экстазе происходит как раз обратный процесс. В экстазе - восстановление божества, его целостности и памяти о себе (см. например эссе «Новые маски» [1904: II, 78], в котором катарсис так тесно связан с припоминанием).

Ценою этого восстановления является забвение человеком себя, его потеря себя. Два сознания одновременно с одинаковой силой существовать не могут, или иначе, говоря ивановскими терминами, выбор лежит между «я есмь» и «Ты Еси». Утверждению божественного в себе, согласно представлениям Иванова, способствует отказ человека от своей личной воли: «дионисийское состояние безвольно» [1904: I, 724]. Одна из центральных идей Иванова в данный период заключается в том, что наивысшая форма проявления личной воли как раз и состоит в отказе от нее.

Разные аспекты этой идеи выражены в формулах «волить безвольно» 18 и «глубочайшей, сверхличной воли человека» 19 . В этом же ключе он понимает евангельское изречение «кто хочет сохранить свою душу, потеряет его» ${ }^{20}$, и этот добровольный отказ от своего эмпирического я составляет ядро ивановского акта «принятия богосыновства» 21.

В системе Иванова экстаз, имея в виду состояние переживающего его человека, - двойственный процесс. Человек в нем преимущественно пассивен: он претерпевает наитие божества, и может этот факт, со своей стороны, утверждать или отвергать. Вспомним, что с метафизической точки зрения Иванов этим определяет «правоту» или «неправоту» безумия. С другой стороны, именно отказом от самого себя, человек может оказаться в этом процессе даже активным, ведь это своеобразное творчество, создавание чего-то большего из самого себя:

16 Кроме статьи «Ницше и Дионис» этот мотив фигурирует в сборнике «По звездам» в эссе «Символика эстетических начал» [I, 830] и «Ты еси» [III, 266].

17 Кроме статьи «Ницше и Дионис» см. еще в эссе «Символика эстетических начал» [I, 830].

${ }_{18}$ Ср.: «Символика эстетических начал» [I, 830]; «Копье Афины» (1904) [I, 837].

${ }_{19}$ Ср.: «Идея неприятия мира» (1906) [III, 83]; «Предчувствия и предвестия» (1906)

[II, 89]; «Ты еси» (1907) [III, 267]; «О „Цыганах,, Пушкина» (1908) [IV, 320].

${ }_{20}$ Ср.: «Ты еси» (1907) [III, 266]; «Две стихии в современном символизме» (1908) [II, 553]; «О русской идее» (1909) [III, 333].

${ }^{21}$ Ср.: «Ты еси» (1907) [III, 266]; «Древний ужас» (1909) [III, 108-109]. 
Лик явленный, сокровенный

Мы сольем, воскреснув, оба:

[1907: III, 134]

Или, на языке понятий:

В дионисийских оргиях ... участник имел перед собой двойственную цель: соучаствовать в оргийном действии ... и в оргийном очищении..., святить и святиться, ... цель теургическую, активную ... и цель патетическую, пассивную... [1906: II, 96].

Но как бы ни венчался успехом процесс экстаза, он, по мнению Иванова, временен. За ним следует повторное отъединение хотя и очищенного, но всё же изолированного человеческого индивида. И это закономерно в рамках этой системы, ведь вспыхивание самосознания эмпирического человека означает угашение в нем самосознания божества:

Вновь разрыв и исступленья, и растерзан Вакх! Эвой! [1905: I, 830]

\section{3. «... в каждый миг истинного экстаза ...» [1904: I, 719]}

Рассматривая онтологию и антропологию Вячеслава Иванова в рамках его дионисийского комплекса идей, мы уже коснулись по необходимости темы экстаза. Необходимость в этом возникла потому, что как раз в экстазе реализуется переход из сферы человеческого в сферу божественного: без экстатического исступления из граней эмпирического $я$ перед человеком не может открыться перспектива его божественного измерения. Теперь следует отдельно рассмотреть ивановские представления об экстазе и катарсисе, ведь это как раз и есть та часть спектра дионисийских идей, которая во весь данный период (1904-1909) остается неразрывно связанной с именем Диониса22. Тема экстаза и очищения так прочно соотнесена в системе взглядов Иванова с именем этого бога, что со временем «дионисийство» в эссеистике Иванова оказывается представленным преимущественно этим своим аспектом.

Поскольку данные идеи Иванова составляют одну из основательно изученных областей его мысли ${ }^{23}$, то я могу позволить себе ограничиться анализом лишь двух аспектов этой темы.

22 Об этом аспекте дионисийства см. в эссе «Ницше и Дионис» (1904) [I, 719]; «Новые маски» (1904) [II, 77-78]; «Символика эстетических начал» (1905) [I, 826 и 830]; «Вагнер и дионисово действо» (1905) [II, 84]; «О Шиллере» (1905) [IV, 178]; «Предчувствия и предвестия» (1906) [II, 93 и 96]; «Ты еси» (1907) [III, 266]; «Байрон и идея анархии» (1908) [IV, 291]; «Эстетика и исповедание» (1908) [II, 571]; «О достоинстве женщины» (1908) [III, 141]; «Спорады»-V (1909) [III, 123-124]; «Древний ужас» (1909) [III, 105].

${ }_{23}$ Ср.: Силард Л. Несколько заметок к учению Вяч. Иванова о катарсисе: СМ II, 143-154; Брагинская H. В. Трагедия и ритуал у Вячеслава Иванова: Архаический ритуал в фольклорных и раннелитературных памятниках. Москва 1988, 296; SzILARD L. A karnevál-elmélet Vjacseszlav Ivanovtól Mihail Bahtyinig. Budapest 1989; Балашов Н. Апокатарсис и дионисийские работы Вячеслава Иванова в издании его переводов Эсхила (серия «Литературные памятники». Москва 1989): Vjaceslav Ivanov. Russischer Dichter - europäischer Kulturphilosoph. Heidelberg 1993, 58-66; WEST J. Ivanov's "Minotaurs of the Mind": 


\section{A. Соответственно принцииу согласования}

Исследуя ивановское учение о катарсисе, Л. Силард подчеркивает, что в центре внимания Иванова стоит «процессуальное преодоление "антиномии полярностей"» как основа катарсиса дионисова культа ${ }^{24}$. Причем это преодоление не означает снятие полярностей, как это постулировано Гегелем в его идее триады ${ }^{25}$. Наоборот, в работах Иванова особенную значимость приобретает идея диады, обнаруживаемая им в дионисийском «обряде сугубой медиации» ${ }^{26}$. На практике катарсисом стало "трехаспектное единство урегулирования отношений»: в душевном хозяйстве - гармонизация отношений между Анимусом и Анимой; внутри социума - упорядочение отношений, прежде всего, в аспекте мужское/женское; и, наконец, упорядочение отношений «человека с Богами, то есть с силами Над-Я»27. Вяч. Иванов, как подчеркивает Л. Силард, раскрывает ту сторону дионисова катарсиса, с которой его влияние не ограничивается сферой богослужений.

...согласующее начало дионисова культа преобразовало все мировосприятие соответственно принципу согласования ${ }^{28}$.

В дальнейшем я хотела бы проследить, как это согласующее начало становится организующим принципом для идейного мира сборника «По звездам».

Нетрудно заметить, что в мировоззренческой системе книги особенно важную роль играет ряд оппозиционных пар. Однако, кажущийся антагонизм составляющих эти пары понятий есть лишь следствие ошибочной установки одной из противостоящих сторон пары и со сменой этой установки тотчас исчезает. Экстаз же в этой системе выполняет функцию катализатора подобной смены установок, говоря ивановскими терминами: исступление из граней эмпирического $я$ есть предпосылка очищения. Рассмотрим теперь подробно, как работает эта схема в ивановских текстах.

В первых эссе сборника Иванов энергично вводит свою проблематику. Двигаясь в хронологическом порядке, в «Поэте и Черни» (1904) подобную противостоящую друг другу пару составляют, с одной стороны, «Чернь» - «начало страдательное и косное» и, с другой стороны, «Поэт» - «действенное начало» [I, 711]. Чернь ждет от Поэта повелений, но тому нечего повелеть ей [I, 709]. Их трагический разрыв, настолько реально ощутимый с пушкинских времен, согласно мысли

Myth, Ecstasy and Reason in the Religious Experience: Vjačeslav Ivanov. Russischer Dichter europäischer Kulturphilosoph. Heidelberg 1993, 365-378.

${ }^{24}$ SZILÁRD L. A karnevál-elmélet Vjacseszlav Ivanovtól Mihail Bahtyinig. Budapest 1989, 55.

25 Силард Л. Несколько заметок к учению Вяч. Иванова о катарсисе: СМ II, 148.

26 Там же.

27 Там же, $150-151$.

${ }^{28}$ SZILÁRD L. A karnevál-elmélet Vjacseszlav Ivanovtól Mihail Bahtyinig. Budapest 1989, 55. 
Иванова, не больше чем иллюзия. Ведь то, что якобы отделяет Поэта от Черни, его «уединение с богом», его «умное делание» [I, 711] - впоследствии обеспечивает «обретение» символа и мифа, где миф понимается как «образное раскрытие имманентной истины духовного самоутверждения, народного и вселенского» [I, 714]. Условие этого - правильное самоопределение Поэта в качестве мифотворца, «органа народного самосознания» [I, 713].

Эту же идею мы находим в эссе «Копье Афины» (1904), где в качестве двух сторон выступает «Поэт» и «Народ» и где акцент стоит на отдельных этапах их разъединения и на возможности его преодоления.

В «Новых масках» (1904), эссе, посвященном, по большей части, теме экстаза и катарсиса, Иванов выдвигает новые аспекты темы. Он представлен, с одной стороны, в оппозиции индивида и общины, что есть не что иное как философское обобщение эстетической проблемы, стоящей в центре предыдущих двух эссе. Так же, как и там, противостояние сторон исчезает вследствие правильного самоопределения одной из них, в данном случае - индивида. Согласно представлению Иванова, уже рассмотренному в главе об антропологическом аспекте дионисова комплекса идей, такое самоопределение возможно только после момента «припоминания», после приобретения опыта своего божественного измерения и, тем самым, и опыта своего глубинного единства с миром и другими людьми. В этом процессе искусство подобно катализатору: оно способствует экстатическому выхождению из граней эмпирического я [II, 76-78]. С другой стороны, подобную же роль на уровне личных человеческих отношений играют любовь и страсть. Для современного человека, утверждает Иванов, выход из себя осуществимее всего в любви: в высших точках любовного экстаза он приобретает опыт «потери себя в другом» и утверждение своего «я» в «ты» [II, 80-82].

Эссе «Новые маски», обобщая, завершает разработку эстетических аспектов проблемы. Этическая же ее сторона рассмотрена Ивановым в целом ряде статей, касающихся мистического анархизма 29. Две якобы противостоящие стороны в этих текстах также индивид и община, но тут, в отличие от предыдущих трех эссе, особенный акцент падает, наряду с идеей приобретения мистического опыта, на втором условии правильного самоопределения человека - на волевом акте ${ }^{30}$ Он обозначен Ивановым термином «принятия богосыновства» и состоит

${ }^{29}$ Из них в сборник «По звездам» включены «Кризис индивидуализма» (1905); «Идея неприятия мира» (1906); «Байрон и идея анархии» (1908); «О „Цыганах“ Пушкина» (1908).

30 Рассмотренное мной в другой работе понятие «метанойя» у Иванова объединяет в себе два этих аспекта: в ней имеют место идеи, выраженные как в концепте «припоминания» так и в концепте «принятия богосыновства». См.: Александрова $A$. «Метанойя» - идея раннего Вячеслава Иванова: Studia Slavica Hung. 46 (2001) 153-159. 
в подчинении личной воли человека воле «живущего в нем бога». Кажущийся антагонизм индивида и общины разрешается, опять-таки, изменением установки: личность должна утверждать себя в «сверхличном» своем измерении, чтобы достичь такого плана бытия, где противостояние личного и общего попросту теряет свой смысл. Ведь

...Сверхчеловеческое - уже не индивидуальное, но по необходимости вселенское и даже религиозное [1905: I, 837].

Проблема, как мы видим, по ходу сборника поворачивается к читателю то эстетической, то общественно-этической своей стороной, но она остается той же и разные ивановские концепты (такие как «сверхиндивидуализм», «соборность», «теургия» или «хор») оттеняют ее разные сферы, дают ее проекцию в разные плоскости бытия. Время от времени появляются в текстах некоторые идейные узлы, где разные аспекты проблемы, представленные своими ключевыми словами-эмблемами, выступают целостно, подчеркивая единство основной проблемы. Вот пример такого «узлового абзаца», из эссе «Вагнер и Дионисово действо» (1905):

Борьба за демократический идеал синтетического Действа, которой мы хотим и которую мы предвидим, есть борьба за орхестру и за соборное слово. Если всенародное искусство хочет быть теургическим, оно должно иметь орган хорового слова. И формы всенародного голосования внешни и мертвы, если не найдут своего идеального фокуса и оправдания в соборном голосе орхестры. В Эсхиловой трагедии и в комедии Аристофана орхестра утверждалась и как мирская сходка; и ею были живы совет Ареопага и гражданское вече Пникса [1905: II, 85] (Курсив авторский. - A. A.).

С 1907 г. идея иллюзорного противостояния двух сторон, исчезающего со сменой установки одного из них, выдвигается Ивановым в мифологизированном облачении. Более сознательная, действенная и индивидуализированная сторона с этого времени выступает как представитель «мужского», а сторона более восприимчивая, инстинктивная и нуждающаяся в водительстве (спасении) - как представитель «женского» начал. Этот мотив не нов, ведь Иванов изначально подчеркивал аспект дионисийства, связанный с полом. Новизна эссе 1907 г. может быть названа мотивной, или, иначе, мифопоэтической. Здесь мы впервые встречаем тот миф, который впоследствии становится существеннейшим для Иванова:

Здесь мы касаемся чего-то рокового в судьбах нашей страны. За весь последний период соборная душа ее была косной и только в лучшем случае восприимчивой. Как мертвая цุаревна, она лежала в гробу и ждала богатыря (Курсив мой. - А. А.) [1907: III, 68].

Этот миф сохраняется в творчестве Иванова вплоть до самого конца, проявляясь во множестве вариантов: можно сказать, что он образует одну из тех перспектив, в которых мир как бы воспринимается и интерпретируется Ивановым. В связи с этим стоит упомянуть интересную работу Томаса Венцловы, где автор рассматривает этот же миф 
в поздней прозе Вяч. Иванова, в «Повести о Светомире царевиче»31. Исследователь указывает на его корни в гностических мифах и на то, что вариант этой концепции отразился в учении Вл. Соловьева о мировой душе. Он отмечает также, что Вячеслав Иванов интерпретирует прозу Достоевского сквозь призму того же мифа.

В процитированной фразе Иванова на первом плане стоит общественный аспект идеи: в нем миф о мертвой царевне, ожидающей богатыря, образно раскрывает взаимоотношения соборного и личного начал в аспекте России. Это направление мысли в данном сборнике будет иметь свое продолжение в эссе «О русской идее», где проблема народа и интеллигенции рассмотрена сквозь призму этого же мифа, хотя уже формально христианизированного:

... интеллигенция всегда знает, что ей нужно идти к народу, но не всегда знает, что ему принести, или, уступая настойчивости первого голоса, все же идет и несет ему не то, чего он хочет, народ же вместе желает общения с интеллигенцией и не хочет такой интеллигенции, какая к нему приходит, - недоразумение, могущее разрешиться только взаимною встречей в третьем, Христовом свете, равно закрытом еще от глаз и интеллигенции и народа [1909: III, 334].

«Мужское» и «женское» начала внутри человеческой души - вот второй, помимо общественного, аспект проблемы. Он вводится в эссе «О любви дерзающей» (1907), которая составляет седьмую часть «Спорад»:

Добродетель внутреннего дерзания есть добродетель солнечности, мужественная Андрэа $(\dot{\alpha} v \delta \rho \varepsilon i ́ \alpha), \ldots$ И есть в нас земная планетарность наша, и добродетель планетарности: восприимчивость к свету, открытость Земли Небу, покорность наитию божественному, наша женская, наша религиозная в собственном смысле этого слова душа, поскольку религиозное чувство есть ... радостный ответ Духу: «се, раба Господня», верное ожидание Жениха в полунощи. Напротив, солнечность наша - начало самоутверждающееся и богоборствующее... [1907: III, 132].

Из приведенных цитат явствует, что оппозиционная пара «мужское - женское» в этих текстах вбирает в себя ту идейную нагрузку, которая была присуща оппозициям «Поэт - Чернь» и «индивид община» в эссе 1904-1905 гг. Но не только: она значительно шире предыдущих, поскольку, кроме эстетического и общественно-этического аспектов, в ней наличествуют и аспекты национальный и мистикопсихологический. Самое подробное и самое общеизвестное изложение мистико-психологического аспекта концепции мужского и женского начал находится в эссе «Ты Еси» (1907). Для нас этот текст особенно интересен тем, что в нем Иванов опять эксплицитно указывает на дионисийские, экстатично-оргиастические корни своих идей о согласующем начале. Таким образом, можно сделать вывод, что эссе «Ты Еси» имеет чрезвычайное значение в мифопоэтическом строении сборника.

${ }_{11}^{11}$ Венилова Т. О мифотворчестве Вячеслава Иванова: «Повесть о Светомире царевиче»: CM II, 38-39. 
Этот текст служит узлом переплетения трех основных мифов книги: о Дионисе, о себя забывшем и забытом боге и о мертвой царевне, ожидающей богатыря:

Переживания экстатического порядка суть переживания женственной части $я$, когда Психея в нас высвобождается из-под власти и опеки сознательного мужеского начала, как бы погружающегося в самозабвение или умирающего, и блуждает в поисках своего Эроса, на подобие Менады, призывающей Диониса. (...) Таковою представляется нам природа того «исступления» или «выхождения из себя», которое в психологическом феномене являет снятие и упразднение граней личного сознания. (...) Психея ищет лучей духа, исходящих из нашего божественного центра, (..) имя которому (...) Небо и Отец в Небе. Но эти духовные лучи реализуются для Психеи в ипостаси богосыновства (...) И на зовы Психеи-Менады мужское я как бы воскресает из смертного сна и облекается в светлое видение Сына, - если (...) его последняя сокровенная воля, - in potentia, - не его воля, но воля Отца. Тогда Психея узнает своего Жениха, ... [1907: III, 264-265].

Последний аспект идеи мужского и женского принципов - аспект космический. Он, по закону тожественности микрокосма и макрокосма, действующему в ивановской системе, отражает собой мистико-психологический аспект. Развит же хронологически он чуть позже: в 19081909 гг. О полной параллели этих двух слоев в ивановской мысли свидетельствует эссе «Древний ужас», где начала мужское и женское выступают уже как символы универсального закона бытия:

Как Душа Мира ищет Жениха в макрокосме, так в микрокосме Земля человека ищет своего иного я и чает приближения Сына. Сыном становится человеческое я только отдачею воли своей тому внутреннему свету, который есть Отец в Небе человека. (...) только сыновство дает ему лицо и силу и власть Жениха. Необходимость есть плоть мира. Те древние люди, которые погибли в старинных катаклизмах, поклонились Плоти, космической Жене, и богиня извергла таких мужей, каких не желала. Ибо они были насильственны, но немощны (...) Она же хочет семян Логоса ( как говорили стоики) [1909: III, 108-109].

Подводя итоги сказанному, следует подчеркнуть, что:

1. Согласующее начало, установленное Ивановым в качестве специфики дионисийского катарсиса, становится одним из образующих принципов идейного мира сборника «По звездам».

2. Оно действует в ряде ситуаций, в центре которых стоит конфликт двух, видимо антагонистических начал. Благодаря опыту экстатического характера, одна из сторон, в силу изменившегося самоутверждения, может резко переменить всю свою жизненную установку и, таким образом, упорядочить в том числе и свои отношения с другой участвующей в ситуации стороной.

3. Подобная ситуация, или, иными словами, разворачивающийся ряд таких событий, с 1907 г. появляется в ивановских эссе как конфликт мужского и женского принципов и выражена мифом о мертвой царевне, ожидающей богатыря. 
4. Этот миф в 1907-1909 гг. вбирает в себя многообразные смысловые оттенки и становится одной из основных точек соотнесения идейного и мифопоэтического мира ивановской мысли того времени, нередко вытесняя собою изначально фигурирующий миф о Дионисе.

\section{Б. «Для нас же ... Дионис прежде всего — правое как ...» [1908: II, 570-571]}

Второй момент, на котором я хотела бы остановиться, говоря о представлениях Вяч. Иванова об экстазе и катарсисе, - это момент гносеологический. Иванов настаивает на абсолютной уникальности познания, приобретаемого в экстатическом опыте. Он подчеркивает, что «проникновение» всего существа человека «во всеединство страдания» упраздняет «самоотчуждение чистого созерцания» [1904: II, 78], или, в том же духе, противоставляет экстаз разуму, а музыку логике [1905: IV, 178]. Ивановские тексты свидетельствуют об убеждении, что весь «дионисийский комплекс идей» может быть освоен человеком лишь „опытно“, то есть благодаря мистическому опыту, полученному не иначе, как в экстатическом переживании. Из вышесказанного ясно почему: если только в экстазе происходит «исступление из граней эмпирического $я$ и приобщение к единству $я$ вселенского» [1904: I, 719], то разумеется, что опыт божественного измерения своего существа человек может получить только в экстатическом состоянии. Во всех других случаях в человеке живет сознание «эмпирического я», со всеми своими границами и сугубо человеческими представлениями. Это же убеждение явствует из следующих слов:

Дионисийское начало ... вполне раскрывается только в переживании, и напрасно было бы искать его постижения — исследуя, что образует его живой состав. ... Одно дионисийское как являет внутреннему опыту его сущность... [1904: I, 719].

Этот мотив «что и/или как» настолько существенен в сборнике «По звездам», что частое его повторение бросается в глаза ${ }^{32}$. В этом случае мы вправе говорить о развитии мотива, поскольку он в сборнике претерпевает существенное изменение. В первые годы рассматриваемого периода (1904-1905) термины «как» и «что» в ивановской системе примерно аналогичны паре «форма» и «содержание» (или: «идеи»). Вячеслав Иванов часто повторяет, что форма и содержание (идея) немыслимы в раздельности: нет формы как таковой, есть только

32 Ср.: «Правда, в книге „По звездам“ стиль автора еще не свободен от влияния школьного философского языка: чувствуется долговременное пребывание автора за границей. Местами встречаются выражения, представляющие буквальный перевод с немецкого и совсем не гармонирующие с общим тоном писания В. Иванова. Например: „человек ищет истинного что и хочет правого как. Что обещает прозрение, как перерождение“ ... И это не раз, а много раз повторяется (см. 60, 61, 82, 208 и т.д. стр. той же книги)» Шестов Л. Вячеслав Великолепный. К характеристике русского упадничества: Русская Мысль, 1916, 10. Цит по: Шестов Л. Сочинения в двух томах, 1. Москва 1993, 245. 
данное воплощение данной идеи, так же как и нет содержания, взятого в самом себе, а есть только идея, о которой мы знаем лишь потому, что она воплощена в какой-то форме. Чаще всего Иванов касается этого вопроса в эстетическом смысле и имеет в виду форму и содержание художественного произведения, но схожую идею мы находим, как это было показано, и в его антропологии, в паре «личины» и «лика». Это позволяет говорить вообще о теории принципа формы у Иванова, и данная теория составляет один из наименее изменяющихся элементов в его мысли, сохраняясь устойчиво до самой «Forma Formans e Forma Formata» (1947), которая в русском переводе заканчивается словами: «Примененная к жизни forma formans раскрывается как принцип личности» [III, 682].

Возвращаясь теперь к сборнику «По звездам», можно сделать вывод, что в нем мотив «что и/или как» поначалу появляется именно в вышеизложенном смысле, как некая параллель к паре «форма идея». В эссе «Ницше и Дионис» Иванов акцентирует их нераздельность: «Дионисийское начало ... вполне раскрывается только в переживании, и напрасно было бы искать его постижения - исследуя, что образует его живой состав. ... одно дионисийское как являет внутреннему прозрению его сущность» [1904: I, 719]. Ницше же, по мнению Иванова, виноват как раз в том, что из моря оргийных переживаний хотел вызвать «некое зрительное что, потом удержать, пленить его, придать ему логическую определенность и длительную устойчивость, как бы окаменить его» [I, 720]; и тем самым он подменил «дионисийское как антидионисийским что» [I, 723]. В статье «Новые маски» подчеркнута та же неотделимость дионисийского «что» от его «как»: «Из лона внутренне пережитого как возникает, правда, и некое что; но это - не логический итог других предпосланных что, а внушение мистическое» [1905: II, 80]. Сходная мысль есть и в эссе «О Шиллере», где мы читаем:

Шиллер должен был бросать некое что на дно своей чаши, чтобы вызвать ее внезапное кипение; ... И мы пьем пену, и впиваем в ней субстанцию учительного разума. А мы хотели бы только чистого заражения экстазом себя потерявшего и все грани забывшего духа; мы хотели бы, чтобы в нас хлынул чреватый хаос, и в самих нас, в бессознательных глубинах наших родил свой творческий логос [1905: IV, 178].

Ясно, что в ивановском тексте «содержание» экстатического состояния отрицается не в принципе: в нем может родиться «логос», но этот «логос» - «алогичен», музыкален, непередаваем понятиями разума.

Кардинально меняется это положение в тексте «Эстетика и исповедание» (1908), где «как» уже явно противоставляется всякому «что»:

Для нас же, как символ известной сферы внутренних состояний, Дионис есть прежде всего - правое как, а не некое что или некоторый кто (...) Ясно, что дионисийский восторг не координируется с вероисповеданием, (...) он находит свое место не в ряду вер и норм, а в ряду внутренних состояний, внутренних методов [II, 570-571]. 
Как истолковать эти слова? В научной литературе неоднократно была повторена мысль о том, что дионисизм, в понимании Иванова, надконфессионален ${ }^{33}$. Яркое ее выражение мы находим в основополагающей статье О. Дешарт, которая служит введением к Собранию сочинений В. Иванова [I, 7-225]. В ней автор пользуется выражением Иванова о том, что Дионис - это некое как, а не что [I, 60], а интерпретирует его следующим образом:

Для греков Дионис был богом, для нас он - жизненно и творчески плодотворный способ, лишь способ вызывать состояния восторга и исступления [I, 49].

Особенный интерес представляют собой слова О. Дешарт о том, что дионисийство именно поэтому «не спорит с христианством»; она пишет даже о наличии двух течений внутри христианства, дионисийского (св. Августин) и аполлонийского (св. Фома Аквинский) [I, 60]. На мой взгляд, О. Дешарт коснулась самой сердцевины вопроса. Действительно, Иванов, говоря, что Дионис - это есть некое как, а н е некое что, утверждает, что дионисийство не спорит с христианством. Примечательно, что он считает необходимым зафиксировать это положение только в статье 1908 г. «Эстетика и исповедание», в качестве возражения А. Белому на его статью «Символизм и русское искусство», которая вышла в 10-м номере журнала «Весы» за 1908 год [II, 814]. Иванов пространно излагает взгляды своего критика и в том числе отмечает:

Попытка изложения моих взглядов в разбираемой статье сопровождается их критикой, исходящей из той мысли, что признание за символом религиозного содержания обязывает к исповеданию религиозных убеждений, каковое не признается достаточно выраженным в моих эстетических опытах. (...) Назвав Диониса как некое «во-имя», начертанное на моем знамени, мой критик обвиняет меня в уклончивости, недоумевая: «Кто Дионис? - Христос? Магомет? Будда? или сам Сатана?» Но ужели должно еще повторять, что, по моему воззрению, Дионис для эллинов - ипостась Сына, поскольку он - «бог страдающий»? Для нас же, как символ известной сферы внутренних состояний, Дионис есть прежде всего - правое как, а не некое что или некоторый кто... [II, 570-571].

В дионисийском комплексе идей Вячеслава Иванова «как» означает установку на мистико-оргиастичный процесс; в то время как под «что» понимается сам приобретенный опыт, само мистическое внушение - т.е. по существу, весь комплекс положительных метафизических идей, как онтологических, так и антропологических и гносеологических. Мы видели, что в ивановской мысли «как» и «что» в действительности неразделимы: только по ходу исступления из граней эмпирического $я$ человек может приобрести опыт своего божественного измерения и своего глубинного единства со вселенной. Формулировка

${ }^{33}$ Cp.: SzILÁRD L. A karnevál-elmélet Vjacseszlav Ivanovtól Mihail Bahtyinig. Budapest 1989, 48; также: Карпи Г. «На пути к страдающему богу». Предисловие [к публикации Вяч. Иванова «О многобожии»]: Вячеслав Иванов: материалы и публикации: Новое литературное обозрение, № 10 (1994) 29. 
«правое как, а не некое что», таким образом, предстает именно как возражение Белому, как отрицание стремления Белого «окаменить» эти идеи в «некотором зрительном что» [I, 720]. В словах Белого звучит требование, очень схожее с тем, что описано Ивановым как «трагическая вина» Ницше, который «ипостазирует сверхчеловеческое как в некоторое что, придает своей фикции произвольно определенные черты» [I, 723]. В ивановской мысли данного периода, как мы видели, именем Диониса обозначена цельная мировоззренческая система, по определению не описуемая точной системой понятий (вспомним что она укоренена в мистическом опыте) и несводимая к какой-либо «конфессии», «религии» или «философии». Именно поэтому она обозначена личным именем античного бога, которое, таким образом, становится носителем мифа в ивановском смысле. Но это только одна сторона дела. Прежде чем, однако, рассмотреть вторую - а именно, спорит ли дионисизм с христианством - необходимо сделать небольшое отступление.

\section{4. «...распятый Дионис...» [1904: I, 721]}

Даже беглый взгляд на сборник «По звездам» улавливает большое число христианских аллюзий. Нет во всей книге ни одного эссе, где хотя бы бегло не упоминалась эта тема. Евангельские изречения, как всем известные, так и реже цитируемые, встречаются в сборнике повсеместно. Не будет преувеличением сказать, чтов этот период Иванов постоянно соотносит свои идеи с христианством.

Стоит обратить внимание, однако, на своеобразие восприятия Ивановым личности Христа и христианства вообще. Специфику этого восприятия можно сформулировать как непосредственную ориентированность друг на друга фигур Христа и Диониса ${ }^{34}$, которая проявляется на разных уровнях текста. Показательно, с этой точки зрения, первое эссе книги «Ницше и Дионис», где словарные запасы, используемые для описания христианства и Диониса, взаимно заменяют друг друга. Дионис тут представлен в терминах христианских:

«Сын божий», преемник отчего престола, растерзанный Титанами в колыбели времен; он же в лике «героя» — богочеловек, во времени родившийся от земной матери [1904: I, 718].

34 Эта особенность восприятия Иванова была отмечена в работе Л. Силард «Аполлон и Дионис (к вопросу о русской судьбе одной мифологемы)». Ср.: «Установка на выявление архетипического позволила Вяч. Иванову (...) с помощью архетипа „страдающего бога“ связать - вопреки Ницше! - Диониса с Христом. Эта поправка была принята, особенно младшими символистами, тем более охотно, что позволила совместить круг „дионисийских“ идей с христологией Вл. Соловьева. Контаминация аттрибутов Диониса и Христа, отсылающая к самим общим приметам страдающего бога, становится частым явлением в символистской поэзии»: Силард Л. Аполлон и Дионис (к вопросу о русской судьбе одной мифологемы): Umjetnost riječi 25 (1981) 157. 
Христианство же, в свою очередь, изображено с использованием аттрибутов Диониса:

в изначальном образе [его] отношения к жизни [оно] есть пронзенный любовью оргиазм души, себя потерявшей, чтобы обрести вне себя, переплескивающейся в отцовское лоно Единого, - нисийский белый рай полевых лилий и пурпурный виноградник жертвенных гроздей, экстаз младенчески-блаженного прозрения в истину Отца в небе и действительность неба на вставшей по-новому пред взором земле» [1904: I, 723].

Вторая особенность восприятия христианства Ивановым состоит в том, что он выделяет несколько особенно значимых для него аспектов, которые неоднократно повторены в статьях сборника. К числу этих аспектов относится:

1. мысль онтологического характера о «тайне Сына», о нисхождении божества ${ }^{35}$ и о рождении богочеловека от земной матери;

2. идея «страдающего бога» 36 , его жертвенной смерти и воскресения;

3. антропологическая интуиция о том, что Бог от человека не отделен пропастью трансцендентности, наоборот, присутствует в нем самом ${ }^{37}$ («Отец в небе»);

4. учение о необходимости метафизического выбора между «богосыновством» и «богопротивлением», или, иными словами, между «расточением» и «сохранением души» ${ }^{38}$;

5. мысль о том, что при выборе богосыновства происходит примирение противоборствующих начал ${ }^{39}$ - «встреча двух в Христовом свете».

Хочу подчеркнуть, что среди этих аспектов нет ни одного, которого бы Иванов не представил в других местах книги в чисто дионисийских терминах, как мы это уже видели в главе «Дионис есть ...» настоящей работы. Таким образом, во всех названных аспектах автор устанавливает соответствие между идеями дионисийства и христианства, что позволяет ему свободно оперировать терминологией двух систем. Об этом свидетельствуют и параллельные места, когда в описании явления равно присутствуют как христианские, так и дионисийские мо-

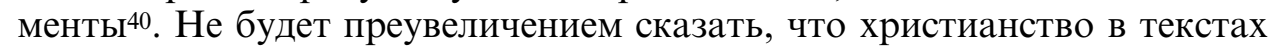

35 Ср.: «Ницше и Дионис» (1904) [I, 718]; «Символика эстетических начал» (1905) [I, 827]; «Две стихии в современном символизме» (1908) [II, 537]; «О русской идее» (1909) [III, 332].

36 Ср.: «Ницше и Дионис» (1904) [I, 718]; «Новые маски» (1904) [II, 78]; «Ты еси» (1907) [III, 266-268].

37 Ср.: «Ницше и Дионис» (1904) [I, 723]; «Ты еси» (1907) [III, 266-267]; «О русской идее» (1909) [III, 330-331]; «Древний ужас» (1909) [III, 108].

38 Ср.: «Ты еси» (1907) [III, 266-267]; «Две стихии в современном символизме» (1908) [II, 553]; «Спорады»-VI (1908) [III, 126]; «О русской идее» (1909) [III, 326 и 330333]; «Древний ужас» (1909) [III, 108].

39 Ср.: «Ты еси» (1907) [III, 265-266]; «Спорады»-VII (1907) [III, 133]; «О русской идее» (1909) [III, 334]; «Древний ужас» (1909) [III, 108-110].

40 Ср. например: «Новые маски» (1904) [II, 78]; «Две стихии в современнос символизме» (1908) [II, 553]; «О русской идее» (1909) [III, 332]. 
данного сборника не появляется само по себе, вне контекста дионисийских идей Иванова. Хотя есть - о чем речь впереди - один единственный аспект в восприятии христианства Ивановым, к которому не находится дионисийской параллели: это касается отношения к тварному миру.

Но спектр идей, связанных с именем Диониса, шире, и среди них есть и такие, которые невозможно интерпретировать христиански. Таковы, в первую очередь, интуиции пантеистические, как, например, рассмотренная в главе 2/А настоящей работы идея субординационизма, выраженная в ивановских концептах «радуги», «соответствий» и «кристалла». Сюда же относятся интуиции, касающиеся женского принципа вообще, женской части человеческого $я$, а также взаимоотношения «мужского и женского» во вселенной или в личности. Следовательно, комплекс идей о Дионисе предстает состоящим из двух частей: из идей, имеющих христианские параллели, и из не имеющих таковых. Дионисизм раннего Вячеслава Иванова, как свидетельствует сборник «По звездам», действительно «не спорит» с его же христианством, в том смысле, что им христианские истины не отрицаются. Дионисийские идеи Иванова представляют собой своеобразное раздвижение границ его христианства. Со стороны Иванова подобное соотношение двух мировоззренческих систем вполне осознано, как это явствует из уже упомянутого экскурса «Эстетика и исповедание»:

Знакомый с моими сочинениями не только знает мое личное положительное исповедание христианства, но, в меру своей восприимчивости к моим словам и к моим намекам, к моей символике и к моей тайнописи, угадывает и мистическую среду, чрез которую преломляется в моей душе свет христианского средоточия моей религиозной жизни [1908: II, 571].

Более того, в подобном явлении Иванов угадывает признак «новой органической эпохи». Ведь двумя годами раньше он писал:

Попытки религиозного синкретизма, попытки введения в христианское сознание элементов всеобразно преломленного в его среде пантеизма, новые, более духовные откровения идеи теократической - все эти разнообразные феномены были симптомами начинающейся интеграции в сфере религиозной [1906: II, 90].

Вопрос, насколько ивановское восприятие христианства соответствует учению Церкви, теперь мною не ставится. Замечу лишь, что исторически-конкретная личность Христа в ивановской системе как бы находится на втором плане. На первом плане же у него стоят связанные с христианской мыслью проблемы космического, антропологического или этического характера. Полноты ради, однако, следует повторить, что уже в этот ранний период творчества Иванова есть одна исключительно христианская интуиция, которой не найти параллели среди идей дионисийства и которая чрезвычайно важна Иванову. В период рассматриваемого сборника эта интуиция предстает в облике идейной основы «мистического энергетизма»: 
Христос раскрыл идею неприятия мира во всей антиномической полноте ее глубочайшего содержания. Он велит «не любить мир, ни всего, что в мире», — и сам любит мир в его конкретности, мир «ближних», (...) Он говорит, что царство его не от мира сего, - и вместе благовествует, что оно «здесь, среди нас». Он тоскует в мире, потому что «мир лежит во зле»; но каждое мгновение сам снимает зло и восстановляет мир истинный, (..) Такое неприятие мира мы называем правым, ибо оно - «непримиримое Нет», из коего уже сияет в своих сокровенных возможностях «слепительное Да». (...) Это христианское неприятие мира составляет принцип мистического энергетизма, движущей силы нашей - явно или латентно - христианской души. «Ибо знаем, что вся тварь совокупно стенает и мучится доныне; и не только она, но и мы сами, имея начаток Духа, и мы в себе стенаем, ожидая усыновления, искупления тела нашего» (Посл. к Римл. 8, 22) [1906: III, 82-83].

Заключительная цитата из апостольского послания в дальнейшем станет одним из опорных мест в произведениях Иванова, и лежащее за нею христианское отношение к тварному миру дает свои отголоски как в плоскости метафизической, так и эстетической.

\section{5. Две структуры: идеи и мотивы}

Подводя итоги вышесказанному, сначала следует воспроизвести в своей целостности тот комплекс идей, который мы обозначали, вслед за В. Ивановым, именем Диониса. Он состоит из следующих главных представлений:

\section{І. В области онтологии}

1. Бог и мир имеют различную природу: Богу присуще единство и бытие (Сущий). Мир призрачен и множественен в своих существах, явлениях (мэ-он: не-сущий).

2. Бог, тем не менее, не отделен от мира, он проникает мир, приводя его к жизни (нисхождение). Сам Бог, однако, при этом теряет свое единство и бытие (страдающий бог, жертва).

3. В результате богонисхождения, мир тоже вмещает в себе Бога. Разные степени близости, проникнутости Богом создают в мире своеобразную градацию: мир приобретает ступенчатое строение. Каждая ступень отражает предыдущую (соответствия), но каждая более и более «вещественно», «воплощенно» (кристалл). Отдельное явление, такми образом, одновременно и скрывает и обнаруживает свою сущность, идею (лик и личина).

4. Мир, благодаря божественной сущности, в ней самой приобретает бытие и единство (всеединство Сущего).

\section{II. В области антропологии}

1. Человеческая душа - это живое зеркало мира; макрокосм и микрокосм тожественны. Эта тожественность представлена в самом человеке присутствием Все-Я, объемлющем вселенную. 
2. Как в мире, так и в можно обнаружить два неравных начала: эмпирическую личность и его божественное средоточие (Я-Сущий и ямэон). Как мир, так и человек вмещает Бога.

3. Но человек, чаще всего, об этом не знает и осознает себя тожественным своей эмпиричесской личности (себя забывший и забытый бог).

4. Человеческое я, как и мир, не есть нечто однородное: в нем присутствуют два начала, женское и мужское. В начальной стадии самоосознавания личности взаимоотношения двух начал не урегулированы и женская часть нередко погружена в сон-смерть (мертвая царевна) или же, наоборот, неистовствует (неистовство Психеи).

5. Вследствие внутреннего экстатического опыта (исступление из граней эмпирического я) наступает момент прозрения, припоминания, узнавания своего божественного измерения ( $T b l E c u)$. После этого эмпирическая личность предстает как личина внутреннего, божественного Лика (воскрешение Лазаря).

6. Это сопровождается волевым актом (метанойя), выбором между следованием своей воле или же воле Сущего в себе. Во втором случае (принятие богосыновства) человек приходит в гармонию с собой, людьми и миром; результат предпочтения своей воли - безумие (расточить или сохранить душу).

7. Если выбор совершен правильно, его результатом является, в частности, гармонизация отношений мужского и женского начал в человеке (невеста узнает Жениха). Демоническое же самоопределение человека - то есть предпочтение личной воли воле божества в себе приводит к окончательному разрыву двух начал в личности, к душевной болезни (менады растерзывают Диониса).

\section{III. В области гносеологии}

1. Такого рода прозрение своего божественного измерения возможно только в экстатическом состоянии, когда грани эмпирического $я$ стерты (экстаз).

2. В этом процессе участвует все существо человека, это своеобразный вид познания (проникновение).

3. Приобретенный опыт алогичен (мистическое внушение) и неотделим от самого мистико-экстатического процеса (что и/или как).

Обращаясь к рассмотрению того, как представлены эти идеи в различных статьях сборника «По звездам», мы увидим, что они без изменения присутствуют в нем от начала до конца: идейный комплекс 
остается неизменным все шесть лет, на протяжении которых писались эссе книги (1904-1909).

Можно сделать наблюдение, что в отдельных текстах Иванов выдвигает на первый план по нескольку аспектов (мотивов), но есть и такие эссе, в которых столь много мотивов сплетено воедино, что их должно рассматривать в качестве отражающих всю систему. Такие суммирующие статьи - «Ницше и Дионис» (1904), «Ты Еси» (1907), «Спорады» (1907-1908-1909), отчасти «О русской идее» (1909) и «Древний ужас» (1909).

Особого внимания заслуживает отношение идейной и мотивной структуры книги, которые, как уже было сказано, только отчасти соответствуют друг другу. Одну и ту же интуицию почти всегда выражает несколько параллельных мотивов, появляющихся то вместе, то в отдельности.

Если рассмотреть статьи книги в хронологическом порядке, обнаруживается любопытная тенденция. Ряд открывает программная статья «Поэт и Чернь». Идейный комплекс, связанный с именем Диониса, впервые целостно изложен в эссе «Ницше и Дионис» (1904). Затем происходит осмысление выводов в направлении эстетическом: «Новые маски», «Копье Афины», «Вагнер и Дионисово действо», «Символика эстетических начал», «О Шиллере» (1904-1905). После этого на первый план выступают этические аспекты, связанные с кризисом личности и индивидуализма: «Кризис индивидуализма», «Идея неприятия мира» (1905-1906). Эстетическое и этическое направления мысли сплетены воедино и представлены в единстве в статье «Предчувствия и предвестия» (1906). Во всех этих статьях рассматриваемые идеи часто выступают без упоминания имени Диониса.

В эссе «Ты Еси» (1907) опять целостно изложен весь комплекс идей. Хотя по сравнению с «Ницше и Дионисом» в самих идеях нет изменений, все-таки между двумя текстами есть существенное различие. В то время как в 1904 г. мысли Иванова были изложены на языке философии и мифологии, в работе 1907 г. они предстают преимущественно в аспекте психологическом, а рядом с ним приведены аналогии как мифологические, так и христианские. Мотивы сборника выстраиваются в своеобразные пары и тройки, в которых одна и та же идея предстает:

1. в философском свете;

2. в аспекте мифологическом (вспомним три господствующих и взаимосвязанных мифа этого периода: о Дионисе, о себя забывшем и забытом боге и о мертвой царевне, ожидающей богатыря); 3. в аспекте христианском.

Стоит отметить, что христианские мотивы образуют параллельный ряд, который не заменяет а сопровождает ряд мифологический. Приведу несколько примеров таких мотивных групп: 


\begin{tabular}{|c|c|c|}
\hline Бог, Сущий & Дионис & Отец \\
\hline Бог страдающий & растерзанный Дионис & тайна Сына \\
\hline $\begin{array}{l}\text { наш божественный центр } \\
\text { Я-Сущий }\end{array}$ & $\begin{array}{l}\text { Сам или Атман } \\
\text { в человеке }\end{array}$ & Отец в Небе \\
\hline женская часть $я$ & $\begin{array}{l}\text { Психея } \\
\text { Менада } \\
\text { Мертвая Царевна } \\
\end{array}$ & \\
\hline мужская часть я & $\begin{array}{l}\text { Эрос } \\
\text { Дионис } \\
\text { Богатырь } \\
\end{array}$ & я, «в ипостаси Сына» \\
\hline $\begin{array}{l}\text { отождествить себя со } \\
\text { своим эмпирическим я }\end{array}$ & $\begin{array}{c}\text { себя забывший и } \\
\text { забытый бог }\end{array}$ & \\
\hline $\begin{array}{l}\text { экстаз: раскрытие } \\
\text { божественного центра и } \\
\text { антиномии личности } \\
\end{array}$ & $\begin{array}{l}\text { Ты Еси } \\
\text { наитие божества } \\
\text { припоминание }\end{array}$ & $\begin{array}{l}\text { воскрешение Лазаря } \\
\text { Отец Наш }\end{array}$ \\
\hline $\begin{array}{l}\text { волевой акт: выбор между } \\
\text { личной и сверхличной } \\
\text { волями человека }\end{array}$ & $\begin{array}{l}\text { правое или неправое } \\
\text { безумие }\end{array}$ & $\begin{array}{l}\text { сохранить / расточить душу } \\
\text { богопротивление (= неправое } \\
\text { богоборство) / богосынов } \\
\text { ство } \\
\end{array}$ \\
\hline $\begin{array}{l}\text { последствие демонического } \\
\text { самоопределения личности: } \\
\text { раскол сознания, душевная } \\
\text { болезнь }\end{array}$ & $\begin{array}{l}\text { пагубное неистовство } \\
\text { Психеи; } \\
\text { растерзание Диониса } \\
\text { Менадами } \\
\end{array}$ & \\
\hline $\begin{array}{l}\text { последствия сверхличного } \\
\text { самоопределения личности: } \\
\text { луч Духа пресуществляет } \\
\text { психическую субстанцию } \\
\text { мужского я }\end{array}$ & $\begin{array}{l}\text { Психея узнает Жениха; } \\
\text { Гиппа принимает } \\
\text { в колыбель Диониса; } \\
\text { Озирис; Вакх }\end{array}$ & рождение Христа в человеке \\
\hline
\end{tabular}

Подобная таблица наглядно демонстрирует, чего Иванову «не хватало в христианстве» в этот ранний период творчества. Как уже было сказано в главе 5, в области антропологии нет христианской параллели идей, касающихся

1. женской части я (и, на уровне космическом, женского принципа бытия);

2. секуляризации современной личности, т.е. тенденции к восприятию человеком себя без своего божественного измерения.

Возвращаясь к сборнику «По Звездам», следует подчеркнуть, что в эссе «Ты Еси» аспекты философский, мифологический и христианский выступают рядом друг с другом, утверждая взаимозаменяемость трех систем на основе тожества психологической реальности, описанием которой они служат.

Далее, в текстах 1907-1909 гг. рассматриваемый нами идейный комплекс появляется в мотивно разных вариантах. В «Спорадах» он изложен целостно на языке мифологии; в эссе «Древний ужас» равную роль играют как мифологический, так и христианский мифологические 
ряды; и, наконец, в работе «О русской идее» сильнее всего звучат христианские мотивы.

Итак, подводя итог всему вышесказанному, можно утверждать постоянство мировоззренческой системы, изложенной Ивановым в разных эссе сборника «По звездам». С другой стороны, в текстах проявляются поиски адекватного способа выражения изначально существующей идейной системы: мы можем констатировать постепенное возрастание в них роли христианских мотивов. Но последняя воля автора, выраженная расположением статей в сборнике, говорит об ином. Вопервых, Иванов, сравнительно немного нарушая хронологический порядок, начинает книгу работой «Ницше и Дионис», выдвигая на первый план рассматриваемые нами дионисийские идеи. Во-вторых, он помещает рядом статьи, близкие по тематике: эстетические, этические и общественные. И, в-третьих (это самое главное), переносит в конец книги эссе «Ты Еси», особенно тем самым акцентируя его. Этим достигается, что первое и последнее эссе служат рамкой всей книги, перекликаясь друг с другом и подчеркивая параллель космическо-мифологического, психологического и христианского рядов. Но - в результате внутри самого дионисийского идейного комплекса последним аккордом звучат не христианские мотивы, а слитые в одну мелодию «симфонию» - мотивные ряды.

\section{6. Предыстория: «О многобожии»}

Набросок «О многобожии»41 был сделан, по мнению публикатора, незадолго до парижских лекций В. Иванова о дионисизме. Уже только поэтому он представляет собой особенный интерес, как один из редких документов самого раннего периода творчества автора. Кроме того, он находится в генетической связи с серией статей «Эллинская религия страдающего бога» и освещает по-новому эту последнюю, ведь их текстуальные совпадения приводят исследователя к выводу, что

...последние две главы «Эллинской религии страдающего бога» отнюдь не являются беспристрастным «теоретическим» обобщением проведенных в предыдущих главах «эмпирических» исследований, но возникли изначально как самостоятельный текст, как первый схематический «манифест» сложившихся a priori религиозно-историософских представлений, по отношению к которым основная, «прикладная» часть «Эллинской религии страдающего бога» является лишь «развитием» a posteriori ${ }^{42}$.

Мы же обращаемся к наброску «О многобожии» как к первому изложению рассматриваемого нами дионисийского комплекса идей.

41 Иванов, В. И. «О многобожии». Публикация Гвидо Карпи: Вячеслав Иванов: материалы и публикации: Новое литературное обозрение, № 10 (1994) 33-39.

42 Карпи, Г. «На пути к страдающему богу». Предисловие [к публикации Вяч. Иванова «О многобожии»]: Вячеслав Иванов: материалы и публикации: Новое литературное обозрение, № 10 (1994) 27. 
Если сравнить текст «О многобожии» с этим комплексом, каким он предстает перед читателем в сборнике «По звездам», то обращает на себя внимание, во-первых, постоянство его основных положений, и, вовторых, - относительно полное изложение всего спектра идей уже тут, в раннем наброске. Более того: в тексте «О многобожии» уже присутствуют многие из будущих устойчивых ивановских формул, повторяющихся впоследствии на страницах «По звездам».

Совпадения нагляднее всего в области антропологии. Основной пафос наброска «О многобожии» в том, что человечество находится в падшем состоянии ${ }^{43}$. Главный же симптом падения заключается в его «обособленности» $(4,35)$, оторванности от Бога $(6,35)$ и от Природы $(4,35)$, т.е. в кризисе его религиозной жизни $(5,35)$. Выход из кризиса мыслится Ивановым как «обращение» и «отвержение себя» $(1,33)$, как «открытие в себе цельных и правильных черт иного, ... неискаженного человека» $(2,34)$. Иванов считает это возможным лишь с помощью «религиозного чувства» как особого вида познания, «постижения религиозного смысла» явлений $(9,36-37)$. С помощью религии «мы познаем наше Я за его эмпирическими пределами» $(10,37)$. Оно таким образом предстоит нам, с одной стороны, как «божественная сущность», и, с другой стороны, как нечто находящееся в «единстве с тем, что вне индивидуума» $(10,37)$. В конечном итоге, в религии человек постигает, по Иванову, «призрачность всякого индивидуума» $(10,37)$. Подобное «духовное перерождение», по существу, есть «Возрождение» $(2,34)$ потому, что человек некогда знал об этих своих измерениях, но теперь не помнит о них: он «себя забывший и забытый бог» $(16,39)$.

Сознать себя в растерзанных частях Единого значит соединиться с Сыном Божим, Дионисом, в существе, и с Изидою-Деметрою в искании: с тем - в страдании разделения и распятия, с этою - в любви и тоске сердца, седмижды прободенного. Верить значит переживать в себе рождение Бога, смерть Бога, воскресение Бога. Любить [значит] - искать $(15,38)$.

В фрагменте «О многобожии» стоит отметить, что в нем фигурируют также идея единства полярностей как качество всякой живой силы $(12,37-38)$ и мысль о наличии «мужского» и «женского» начал как в человеческой душе $(15,38)$, так и в космосе $(16,38-39)$.

В области гносеологии важнейшее положение наброска в том, что «религиозный смысль есть особенный, специфический дар духа» $(9,37)$, не сводимый к другим проявлениям деятельности духа, например к философии или вообще к науке. Вера же, со своей стороны, есть «лишь род созерцания и воления» $(9,37)$. На основе вышесказанного Иванов сделает этические выводы, заключающиеся в том, что «религия ... родник экстатических очищений», музыка которого «не может быть переведена на язык нетрансцендентной воли и стать критерием прак-

43 Там же, 33. Далее я ссылаюсь на эту публикацию «О многобожии» в тексте, указывая вначале номер параграфа, а потом страницу, например: $(1,33)$. 
тических решений» $(11,37)$. Но экстатическое очищение тем не менее приводит и к этическим последствиям, хотя и не согласуемым и не описуемым в понятиях формальной этики. Имеется в виду та самая мысль о «погружении личной воли в единство воли божественной» $(13,38)$, которая станет впоследствии центральной идеей мистического анархизма.

В области онтологии пространнее всего развернуты идея всеединства (параграфы 4, 5, 6, 8, 14, 18) и страдающего бога (параграфы 7, 8, 15). Из более поздних идей отсутствует мысль о взаимоотношении «Сущего» и «мэона» во вселенной, а также идея «соответствия» как основного принципа строения мира.

Пока мы оставили в стороне вопрос о самом наброске, о его композиции и сюжете. Публикатор его отметил в своих текстологических замечаниях, что «текст из восемнадцати «главок», как нам кажется, представляет собою некоторое композиционное целое»44. Он же определил жанр наброска как «серию афоризмов» 45 и назвал его ",манифестом,, сложившихся a priori религиозно-историософских представлений» ${ }^{46}$.

Композиция текста «О многобожии» основана на аккуратно выдержанном принципе рамки. Параграфы затрагивают три сферы:

1. тему современного кризиса духа;

2. сферу истории религии, содержа наблюдения относительно трех античных религий: «семитской» (а), «орфической» (б) и «христианской» (в);

3. область теории, развивая религиозно-философские моменты.

Три названных плана чередуются в восемнадцати параграфах в следующем порядке:

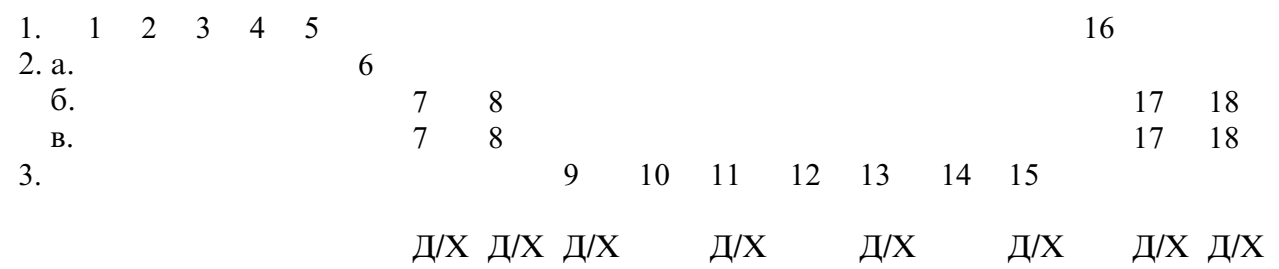

Уже в первых параграфах выражена основная идея всего текста: выход из кризиса заключается в «обращении» $(1,33)$ и «возврате» $(2$, $34)$ - духовное «перерождение» означает «возрождение» $(2,34)$. Предложение «мы хотим духовного перерождения ... которое совершилось бы, если человек, углубившись в себя, открыл бы в себе цельные и правильные черты иного, древнего человека» $(2,34)$ во втором варианте

\footnotetext{
44 Там же.

45 Там же.

46 Там же, 27.
} 
этого параграфа изменено: слово «древнего» заменено словом «неискаженного». Подобная смена хорошо демонстрирует, что «возврат» Ивановым понимается не исторически, а как бы «идеалистически»: он есть возвращение к некоторому «золотому веку», точнее не очерченному «до-семитскому» периоду в истории религиозной жизни человечества. В шестом параграфе развита мысль, что идея творения сама по себе пролагает «бездну между Богом и миром» $(6,35)$. Бездна, дотоле не существовавшая, «перейдена» христианской идеей «мистической филиации» $(6,35)$. В седьмом и восьмом параграфах утверждается параллель религии орфического Диониса с христианством, на основе отсутствия - еще и уже - этой бездны. Центральная часть наброска (параграфы 9-15) посвящена изложению тех религиозно-философских идей, которые мы рассмотрели в начале данной главы. В них обнаруживаются основы дионисийского комплекса идей, рассмотренного выше на материале сборника «По звездам». Заключительная часть (параграфы 16-18) как бы обрамляет набросок, опять возвращаясь к теме кризиса современного духа и к мысли о выходе из кризиса путем «возврата» разделенного в себе современного человека: «припоминания» «себя забывшего и забытого бога» $(16,39)$. Две короткие главки в конце повторяют интуиции седьмого и восьмого параграфов о параллелях орфического дионисийства с христианством.

«Золотой век», к которому призван вернуться современный человек, мыслится как некое примирение этих двух религиозных систем. Данная идея имеет настолько центральное значение в наброске, что не только обрамляющие параграфы, но и средняя, религиозно-философская его часть пронизана ею. В каждом втором ее параграфе фигурирует мысль об аналогиях между орфическим дионисийством и христианством в различных аспектах: я обозначила их в схеме буквами «Д» и «Х», чтобы было нагляднее видно ритмическое повторение данной мысли. Напомню еще раз, что Иванов понимает «возврат» не в смысле возвращения к определенной историко-религиозной ситуации. «Золотой век», как свидетельствует набросок «О многобожии», достигается даже не «синтезом» двух религиозных систем: он понимается Ивановым как такое изменение человеческого восприятия себя и мира, после которого кажущееся противоречие двух религий само собой исчезает. Подобное сближение двух религий, говорит Иванов, даже исторически «вернее» других:

«Исторический смысл» (,historischer Sinn“) - не в том, чтобы понять древность как условие и обусловленное, но как порыв и достигнутое $(1,29)$.

Глубинный идеализм ивановских мыслей объясняет «принципиальный антиисторизм» ${ }^{47}$ текста. В наброске «О многобожии» отражены, в первую очередь, не «религиозно-историософские представления» ${ }^{8}$

47 Там же.

48 Там же.

Studia Slavica Hung. 46 (2001) 
Иванова. Религиозно-исторические наблюдения вторичны по сравнению с мыслями из области философии религии, появляющимися в основной части текста (параграфы 9-15). Больше того: хотя моменты из истории религии уже изначально интерпретируются в духе собственных же религиозно-философских представлений и их роль скорее иллюстративна, тем не менее, по замыслу текста, они поданы как наблюдения, из которых вытекают выводы теоретического характера. Это, по сути, есть та же самая техника обращения Иванова со своим материалом, которую Г. Карпи заметил в «Эллинской религии страдающего бога» и вслед за Н. В. Брагинской назвал «конструктивным пафосом»:

...последние две главы «Эллинской религии страдающего бога» отнюдь не являются беспристрастным «теоретическим» обобщением проведенных в предыдущих главах «эмпирических» исследований, но возникли изначально как самостоятельный текст, как первый схематический «манифест» сложившихся a priori религиозно-историософских представлений, по отношению к которым основная, «прикладная» часть «Эллинской религии страдающего бога» является лишь «развитием» a posteriori». ${ }^{49}$

Подводя итоги сказанному, можно сделать следующее заключение:

1. Идейный мир ивановских текстов, реконструкцию которого мы осуществили на основе сборника «По звездам», в главных своих чертах сформулирован уже двумя годами раньше написания первых эссе сборника (1904) — в период наброска «О многобожии» (1902 или 1903).

2. Идеи наброска «О многобожии» не претерпевают существенных изменений и в последующие годы (нами они были рассмотрены в эссеистике Иванова до 1909 года), но развертываются, дополняются и служат основой различных частных теорий.

3. В наброске «О многобожии» эти идеи уже тесно связаны с именем Диониса (в 12 главках из 18 упоминается его имя), хотя, по замыслу текста, они не выведены непосредственно из дионисизма.

4. Тот факт, что в тексте «О многобожии» уже полностью разработана антропология последующей ивановской эссеистики, в то время как онтология представлена лишь некоторыми, правда основными, идеями, позволяет предполагать, что учение о человеке в идейном мире текстов Иванова первично по сравнению с учением о мире. Это, кстати сказать, весьма созвучно убеждению Иванова, высказанному им в конце статьи «Ты Еси»:

«Из микрокосма, как из горчичного зерна, должно вырасти грядущее религиозное сознание, - тогда как большинство исторических вероучений ... отправлялось от идеи макрокосма» (III, 267-268).

49 Карпи Г. «На пути к страдающему богу». Предисловие [к публикации Вяч. Иванова «О многобожии»]: Вячеслав Иванов: материалы и публикации. Новое литературное обозрение, № 10 (1994) 27. 
5. Сам набросок претендует быть воспринятым как серия афоризмов на тему истории религии, в то время как исторические его суждения оказываются вторичными по сравнению с центральными мыслями религиозно-философского характера.

6. Такое соотношение двух частей отражено и в композиции наброска «О многобожии», в свою очередь весьма обдуманной и выдержанной.

7. Способ обращения Иванова со своим материалом - в данном случае историческим - один и тот же в наброске «О многобожии», в «Эллинской религии страдающего бога» и в эссе сборника «По звездам»: а. В духе изначально существующего идейного комплекса интерпретируются моменты из истории религии [«О многобожии»], дионисизм [«Эллинская религия страдающего бога»] и самые разные явления культуры [«По звездам»].

б. Проводится анализ данных, уже своеобразно воспринятых явлений.

в. В качестве итогов анализа представлен тот же самый, уже изначально сложившийся идейный комплекс.

8. В результате подобной техники вокруг изначального сгустка идей вырастает некий своеобразный космос, многоплановый виртуальный мир, в котором отдельные пласты и суждения взаимно поддерживают друг друга: внутри этого мира все стройно, закономерно и правильно. Отсюда вытекает то отмеченное наукой свойство ивановских произведений, что они явно рассчитаны быть воспринятыми именно изнутри: читателю надлежит войти в своеобразный космос текстов Вячеслава Иванова и принять их язык. 